Maurer School of Law: Indiana University

Digital Repository@ Maurer Law

Indiana Law Journal

Volume 83 | Issue 1

Article 7

Winter 2008

\title{
Constitutional Possibilities
}

Lawrence B. Solum

University of Illinois College of Law.

Follow this and additional works at: https://www.repository.law.indiana.edu/ilj

Part of the Constitutional Law Commons

\section{Recommended Citation}

Solum, Lawrence B. (2008) "Constitutional Possibilities," Indiana Law Journal: Vol. 83 : Iss. 1 , Article 7. Available at: https://www.repository.law.indiana.edu/ilj/vol83/iss1/7

This Essay is brought to you for free and open access by the Law School Journals at Digital Repository @ Maurer Law. It has been accepted for inclusion in Indiana Law Journal by an authorized editor of Digital Repository @ Maurer Law. For more information, please contact rvaughan@indiana.edu.

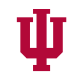

JEROME HALL LAW LIBRARY

INDIANA UNIVERSITY

Maurer School of Law
Bloomington 


\title{
Constitutional Possibilities ${ }^{\dagger}$
}

\author{
LAWRENCE B. SOLUM
}

\section{INTRODUCTION: The PROBlem OF ILLUSORY CONSTITUTIONAL POSSIBILITIES}

What are our constitutional possibilities? The importance of this question is illustrated by the striking breadth of constitutional possibilities discussed recently in high constitutional theory. Contemporary constitutional theory ranges from Sotirios Barber's reading of the United States Constitution as a guarantee of fundamental economic equality ${ }^{1}$ to Randy Barnett's call to restore a lost constitution that guarantees individual liberty. ${ }^{2}$ The range of constitutional options includes James Fleming's perfectionist reading of the Constitution as a charter for deliberative autonomy ${ }^{3}$ and Sanford Levinson's proselytization for a revolutionary program of constitutional redesign that would abolish the Electoral College and equal representation of the states in the Senate. ${ }^{4}$ Are these constitutional possibilities real or illusory? And how can we answer that question?

Theorists like Barber, Barnett, Fleming, and Levinson are conventionally understood as placing constitutional options on the table and as proponents of their

$\dagger$ (C) 2007 by the Author. Permission is hereby granted to duplicate this paper for scholarly or teaching purposes, including permission to reproduce multiple copies or post on the Internet for classroom use and to quote extended passages in scholarly work, subject only to the requirement that this copyright notice, the title of the article, and the name of the author be prominently included in the copy or extended excerpt. Permission is hereby granted to use short excerpts ( 500 words or less each, so long as the total word count of the excerpts does not exceed $50 \%$ of the total word count of the paper) with an appropriate citation and without inclusion of a copyright notice. In the event of the death or permanent incapacity of the author, all claims to copyright in the work are relinquished and the work is dedicated to the public domain in perpetuity. Even if the author is then living, all copyright claims are relinquished as of January $1,2050$.

* John E. Cribbet Professor of Law, University of Illinois College of Law. I owe thanks to Amitai Aviram, Mitch Berman, Laurie Claus, Lee Anne Fennell, Kurt Lash, Jeff Lipshaw, James Pfander, Ekow Yankah, and Mariah Zeisberg for comments, criticisms, and helpful suggestions. An earlier version of this paper was presented to Colloquium on Constitutional Law and Legal Theory at the University of Texas, the faculty of the University of Minnesota School of Law, at the panel entitled Author Meets Critics, Our Undemocratic Constitution at the Association of American Law Schools 2007 Annual Meeting, and to the Conference on an Eighteenth Century Constitution in a Twenty-First Century World at the University of Maryland School of Law in December 2006-I am grateful for comments, criticisms, and suggestions at these events. I owe a special debt of gratitude to Sandy Levinson for his thoughtful replies and to Mark Greenberg for detailed and illuminating comments that both sharpened the argument and made its expression more consistent and precise. Residual errors are, of course, entirely my responsibility.

1. Sottrios A. Barber, Welfare AND the CONSTITUTION (2005).

2. Randy E. Barnett, Restoring the lost Constitution: The Presumption of LIBERTY (2004).

3. James E. Fleming, Securing Constitutional Democracy: The Case of Autonomy (2006).

4. SANFORd LEVINSON, OUR UNDEMOCRATIC CONSTITUTION: Where the CONSTITUTION Goes Wrong (And How We the People Can Correct It) (2006). 
adoption-in other words, as advocates of constitutional change. Normative constitutional theory asks the question whether these options are desirable-whether political actors (citizens, legislators, executives, or judges) should take action to bring about their plans for constitutional reform or revolution. Frequently, normative constitutional theories are criticized on the ground that they are undesirable, unwise, or inconsistent with the best theories of political morality and legitimate legal authority, but sometimes one hears a very different form of criticism, expressed in locutions such as the following: "That is unrealistic." "That's not possible." "That is pie in the sky." "You are imagining castles in the air." "Your suggestion is utopian." "That isn't feasible." These objections invoke the idea of illusory constitutional possibilityconstitutional options that are not actual possibilities.

This Essay addresses issues of constitutional possibility and necessity: What are our constitutional possibilities? How should we think about the feasible choice set for constitutional change? What are the differences between ideal and nonideal theory? What role should the ideas of path dependency and of second best play in constitutional theory? These inquiries cross the lines between normative, positive, and conceptual constitutional theory. At the conceptual level, we can analyze the content and meaning of phrases like "constitutional possibility," "ideal theory," and "the feasible choice set." At the level of positive constitutional theory, we can ask about the forces and institutions that condition constitutional possibility. At the level of normative constitutional theory, we can ask about the implications of constitutional possibility for political morality. ${ }^{6}$

Our investigation of constitutional possibility will proceed as follows. Part I will cobble together a conceptual toolkit for thinking about possibility and necessity in constitutional theory: the tools will range from the familiar distinction between ideal and nonideal theory to a quick and dirty guide to the metaphysics of modality. Part II discusses three errors: the reduction of possibility to cost, the inference of practical possibility from conceivability, and the confusion of possibility and probability. Part III will explore the implications of the resulting proto-theory of constitutional possibility in two stages: stage one will investigate the normative implications, whereas stage two will reconnoiter a set of standards for making modal claims in constitutional arguments. Part IV provides two case studies in constitutional possibility: Sanford Levinson's proposal for a Convention to enact structural reform of the United States Constitution, and Justice Antonin Scalia's argument for originalism

5. I do not intend to take a stand on the methodology or utility of conceptual analysisbeyond the minimalist point that such analysis can, at the very least, clarify the obscure, disambiguate the ambiguous, and specify the vague.

6. Before we proceed further, we should note meanings of the phrases "constitutional possibility" and "constitutional necessity" that are related to, but distinct from, the sense in which the phrase is used in this paper. We could use the phrase "constitutional possibility" to refer to those legal actions (in the broad sense that includes executive actions and orders, rules and legislation, and judicial decisions) that are possibly in compliance with or authorized by the constitution of some jurisdiction-that is, possibly constitutional under the United States Constitution. Similarly, the phrase "constitutional necessity" could be used to refer to those legal actions that are required by a constitution. And finally, constitutional necessity might be used in connection with the "necessary and proper clause" of the United States Constitution. For the most part, these senses of constitutional possibility and necessity will be set aside for the remainder of this essay. 
as a method of constitutional interpretation. The Essay concludes with the problem of false constitutional necessity.

\section{A CONCEPTUAL TOOLKIT FOR THINKING ABOUT CONSTITUTIONAL POSSIBILITY}

How can we think about constitutional possibility? This Part suggests a toolkit with eight elements: (1) an explication of the distinction between ideal and nonideal constitutional theory; (2) the idea of a constitutional second best; (3) path dependency; (4) the notion of the feasible choice set; (5) agent relativity; (6) the scope of decision problem; (7) a quick and dirty guide to the metaphysics of modality; and (8) a very short introduction to positive constitutional theory.

\section{A. The Distinction Between Ideal and Nonideal Constitutional Theory}

One way to think about constitutional possibilities begins with the distinction between ideal constitutions and constitutions that are made for a world that is less than ideal. This distinction can be approached by borrowing the distinction between "ideal" and "nonideal" theory from John Rawls. ${ }^{7}$ By "ideal theory," Rawls means to refer to a moral or political theory that satisfies a condition of "full compliance" or "strict compliance." Nonideal theory studies conditions of "partial compliance," and hence addresses topics such as theories of punishment, civil disobedience, and justified revolution. ${ }^{8}$ Thus, we can ask:

What principles ought a society to adopt for the purposes of designing its institutional structure on the condition that all of the institutions in society conform to these principles? ${ }^{9}$

The parallel question of normative constitutional theory might be phrased as follows:

What constitution ought a society to adopt for the purposes of designing its basic legal structure on the condition that all of the institutions in society conform to the constitution?

In other words, we can ask what constitution we ought to adopt, assuming that perfect compliance - each branch of government always respecting the limits on its power and the rights (if any) that the constitution confers on individuals.

By way of contrast, we can ask questions of nonideal constitutional theory:

What constitution ought a society to adopt for the purposes of designing its basic legal structure on the condition that the institutions of society will violate the constitution to the extent, and under the circumstances, that are predicted on the best understandings of human psychology and political science?

7. See JOHN RAWLS, A THEORY OF JUSTICE 7-8, 215-16,308-09 (rev. ed. 1999); Michael Phillips, Reflections on the Transition from Ideal to Non-Ideal Theory, 19 Noûs 551 (1985).

8. See RAWLS, supra note 7 , at 8.

9. Phillips, supra note 7, at 553. 
That is, we might assume that constitutional actors will sometimes fail to comply with their constitutional duties by exceeding their allocated powers or violating the constitutional rights of individuals. Of course, the conditions for departure from perfect compliance can themselves be varied by making different assumptions about human psychology and institutional behavior or in some other way. Nonideal constitutional theory deals with the unconstitutional; the institution of judicial review might be seen as a paradigmatic topic for nonideal constitutional theory. ${ }^{10}$

It seems obvious that ideal and nonideal constitutional theories may differ. For example, because ideal constitutional theory assumes perfect compliance, the ideal constitution might dispense with the institution of judicial review, whereas nonideal theory might posit the necessity of such review in order to correct constitutional violations. Similarly, nonideal constitutional theory might adopt a constitutional rule that would not be ideal, but that would produce the best consequences given imperfect compliance. For example, the executive might be given a sphere of power more constrained than would be ideal because of an assumption that the executive will overreach and enlarge the sphere of executive power beyond constitutional limits.

How does the distinction between ideal and nonideal theory relate to possibility? One might think that ideal theory deals with that which is not possible, whereas nonideal theory deals with the realm of that which is possible, but which would be a mistake. Perfect compliance may be impossible, but there is no a priori reason to believe that this is always so. Some constitutional provisions regularly result in perfect compliance. No President has been younger than 35 years of age; no state has had three Senators seated simultaneously; no state has opted for a monarchical form of government. Indeed, in cases like these, less than perfect compliance may be very unlikely or even "impossible" in some sense. Nonetheless, for a wide range of cases, perfect compliance may not be feasible and nonideal constitutional theory may be the norm.

The better understanding of the relationship between ideal and nonideal theory is that ideal theory allows us to bracket certain kinds of impossibility-we can explore the implications of making unrealistic assumptions about compliance with constitutional norms. Nonideal theory allows us to explore the implications of realistic assumptions about human nature and social organization that (under some circumstances) make unconstitutionality a central problem for constitutional theory. The ideal and the impossible are not equivalent, but they are related in an important (if contingent) way.

For this reason, the distinction between ideal and nonideal theory is an important tool for normative constitutional theory. The enterprise of ideal theory circumvents certain recurring types of impossibility objections--it allows us to engage in normative investigation while we set some issues of feasibility to the side. The enterprise of nonideal theory puts those feasibility issues back on the table. At an even more abstract level, Rawls's distinction between ideal and nonideal theory points to the more general conceptual tool-the idealizing assumption, an essential component in a variety of

10. Of course, other institutions (such as congressional committees or executive offices) may deal with unconstitutionality outside the courts. See generally James E. Fleming, The Constitution Outside the Courts, 86 CORNELl L. Rev. 215 (2000); Laurence Gene Sager, Fair Measure: The Legal Status of Underenforced Constitutional Norms, 91 HARV. L. REV. 1212 (1978). 
formal models (for example, economic and positive political theory models). ${ }^{11}$ The movement between ideal and nonideal theory suggests the more general phenomena of making and then relaxing idealizing assumptions - including idealizing assumptions about possibility and feasibility. Idealizing assumptions allow the normative issues to be framed clearly and simply; relaxing those assumptions enables the move from constitutional theory to constitutional practice.

\section{B. The Idea of a Constitutional Second Best}

A second tool for reflection upon constitutional possibilities is the idea of a constitutional second best. ${ }^{12}$ To employ this tool, we can borrow economic theory's distinction between "first-best" and "second-best" states of affairs. ${ }^{13}$ The general idea of the theory of the second best can be expressed as follows. Assume a system with multiple variables. Take the most desirable state the whole system could assume and the associated values that all of the variables must assume to produce this state: call this condition the first-best state of the system and call the associated values of the variables the first-best values. Now assume that at least one variable cannot assume the value necessary for the first-best state of the whole system: call this (or these) the constrained variable(s). Identify the most desirable state the whole system could assume given the constrained variable and the associated values that all the unconstrained variables must assume to produce this state: call this the second-best state of the system. There are systems in which achieving the second-best state will require that at least one variable other than the constrained variable assume a value other than the first-best value: call this value the second-best value. One expects that there are examples where many or even all variables must assume second-best values.

11. See generally Daniel M. Hausman, Philosophy of Economics, in STANFORD ENCYClOPEDIA OF PHILOSOPHY, Sept. 12, 2003, http://plato.stanford.edu/entries/economics/ ("Economics raises questions concerning the legitimacy of severe abstraction and idealization. For example, mainstream economic models often stipulate that everyone is perfectly rational and has perfect information or that commodities are infinitely divisible. Such claims are exaggerations, and they are clearly false. Other schools of economics may not employ idealizations that are this extreme, but there is no way to do economics if one is not willing to simplify drastically and abstract from many complications.").

12. What is the relationship between the economic distinction between first best and second best and the philosophical distinction between ideal and nonideal theory? Clearly the two notions are related, and one might be tempted to equate "first best" with "ideal" and "second best" with "nonideal." If these phrases are used loosely (and acknowledged as such), there is no problem with this equation. We could simply stipulate that "ideal" means "first best." But in their technical senses, the two notions overlap but are not identical. Perfect compliance might be worse than imperfect compliance, so the "ideal" theory might be about the "second-best" state of the system. Compliance may not be the only relevant variable that could be constrained, so there could be "second-best" states of the system that cannot be differentiated from "first-best" states on the basis of the ideal/nonideal distinction. However, when compliance is the constrained variable and perfect compliance produces the best state of the system, there is a relevant mapping between ideal and nonideal theory and first-best and second-best states of the system.

13. See generally R.G. Lipsey \& Kelvin Lancaster, The General Theory of Second Best, 24 REV. ECON. STUD. 11 (1956) (articulating the theory of second best in economics). 
Notice that the formal economic idea of the second best is always relative to which variables are constrained. To take a very simple illustration: if a system has three variables $(a, b$, and $c)$, there could be three "second-best" states of the system-one relative to the assumption that variable $a$ is constrained, another relative to assumed constraint of $b$, and a third relative to assumed constraint of $c$. More generally, what counts as second best depends on assumptions about the set of possible or feasible choices. Outside of formal theory, there may be a fact of the matter about which variables are constrained, and hence there may be a unique constitutional second best.

The idea of a constitutional second best is found in Cass Sunstein and Adrian Vermeule's work on constitutional interpretation and institutional capacity. ${ }^{14}$ In the course of making their argument for simple-minded formalism as the second-best theory of constitutional interpretation, Sunstein and Vermeule argue that the institutional capacities of judges are a constraining variable. ${ }^{15}$ In particular, judicial capacity may not be able to assume the value required by the first-best theory of constitutional interpretation. ${ }^{16}$ Therefore, another variable, that is the normative theory of interpretive methodology must assume a second-best value in order to produce the second-best state of the system of constitutional interpretation. In other words, if the judiciary lacks the institutional capacity to do what first-best theories require, then an institutional theory is required in order to produce second-best outcomes. For this reason, "institutional analysis is necessary, even if not sufficient, to an adequate evaluation of interpretive methods." 17

The notion of a "constitutional second best" should be differentiated from the role that the second best plays in formal economic theory. In that realm, the notion of a constrained variable is treated as an assumption: given that variable $v$ cannot be assigned its first-best system value $p$ then the second-best state of the whole system requires that variable $u$ assume value $r$ and not its first-best system value $q$. The notion of a constrained variable operates in a formal model-which may or may not be accurate or useful as a description of the world. Normative constitutional theory is rarely "formal": concepts like "legitimacy," "rights of political morality," and "coherence of the legal materials" create difficult, if not intractable, problems of formalization. So the idea of a constitutional second best should not be understood on the model of an assumed constraint on a variable. Rather, the idea is that certain choices or options are outside the set of choices that are feasible or possible. Secondbest constitutional outcomes are understood as the products of choices made by actual constitutional actors - that is, as states of the world rather than as states of formal models.

\section{Path Dependency}

The general idea of path dependency is that prior decisions constrain (or expand) the subsequent range of possible or feasible choices. ${ }^{18}$ That is, a decision, $d$, made at

14. Cass R. Sunstein \& Adrian Vermeule, Interpretation and Institutions, $101 \mathrm{MICH}$. L. REV. 885 (2003).

15. See id. at 914 .

16. Id.

17. Id. at 915 .

18. See Paul Pierson, Politics in Time: History, Institutions, and Social Analysis (2004); Paul Pierson, Increasing Returns, Path Dependence, and the Study of Politics, 94 AM. POL. SCI. REv. 251 (2000). The discussion in the text focuses on path dependency in the context 
time $t_{1}$ may affect the choice set, $S=\left(c_{1}, c_{2}, \ldots c_{n}\right)$, at time $t_{2}$. We can define a choice set as a set of actions that a given agent could take. Or to expand the path metaphor, if we imagine a network of paths through time, from past to future, decisions to branch at an earlier point on the chosen path may affect the destinations that one can reach from a later point on the path. Sometimes, if we choose the left fork, we may be able to reach exactly the same destinations we could have reached via the right fork, but other times, our choices foreclose some possibilities altogether. It isn't always the case that in the long run, there's still time to change the road you're on. ${ }^{19}$

This general notion can be specified in various ways. First, we can specify the type of effect that a decision has on the choice set. One type of effect is an effect on which actions are members of the choice set. Thus, by making a decision $d$ at $t_{1}$, the resulting choice set at $t_{2}$ would have members $c_{1}, c_{2}$, and $c_{3}$, but if the decision had been $d^{\prime}(d$ prime), then the choice set at $t_{2}$ would have members $c_{1}, c_{3}$, and $c_{4}$. In this illustrative case, making decision $\mathrm{d}$ rather than $\mathrm{d}^{\prime}$ both added and subtracted from the choice set at $t_{2}$. Another type of effect is an effect on the costs associated with the actions that are members of the choice set. That is, decision, $d$, might result in the price of a given choice $P\left(c_{1}\right)$ being greater than that price would have been if an alternative decision, $d^{\prime}$, had been made. Notice, however, that if we include price in the specification (or description) that designates a choice, then this second type of effect (that is, a cost effect) is reducible to the first type of effect (a possibility effect).

A second way in which we can specify the general notion of path dependency is to describe the causal pathway by which decisions affect future choices. On the one hand, one might use the phrase "path dependency" to refer to all causal mechanisms. ${ }^{20}$ On the other hand, we could reserve the phrase for a specific type of causal mechanism. For example, Paul Pierson has suggested that the notion of path dependency should be limited to what he calls "positive feedback." 21 Positive feedback (or selfreinforcement) involves the idea that as time progresses, the relative benefit of maintaining some feature of the system (and hence the relative costliness of modifying or eliminating that feature) increases. Once a constitution has been adopted and gone into effect, it becomes more costly to adopt a different constitution. Once a federal system has been created out of sovereign subunits, it becomes more costly to eliminate the federal (or national) government. Once a judicial precedent has been established and relied upon, the costs of reversal grow.

A third way in which we can specify the idea of path dependency is by differentiating between the ways in which path dependency might lead to suboptimal outcomes. $^{22}$ Following Liebowitz and Margolis, ${ }^{23}$ we can distinguish three possibilities. First, in some cases, the decision, $d$, at $t_{1}$ may have been the best possible

of decision and choice, but the notion could be generalized to include causal processes that do not involve choice.

19. See Led ZEPPELIN, Stairway to Heaven, on Led ZEPPELIN IV (Atlantic 1971).

20. William H. Sewell, Jr., Three Temporalities: Towards an Eventful Sociology, in THE Historic TURN IN THE HUMAN SCIENCES 245, 262-63 (Terrence J. McDonald ed., 1996) (describing the idea of path dependency as "that what has happened at an earlier point in time will affect the possible outcomes of a sequence of events occurring at a later point in time").

21. PIERSON, supra note 18 , at 20-21.

22. Id. at 28; see also Oliver E. Williamson, Transaction Costs Economics and Organizational Theory, 2 INDUS. \& CORP. CHANGE 107 (1993).

23. S.J. Liebowitz \& Stephen E. Margolis, Path Dependency, Lock-in, and History, 11 J.L. ECON. \& ORG. 205 (1995). 
decision - the consequences are "path dependent" (caused by d), but no better outcome was possible. Second, in other cases, it may be that there was an alternative decision, $d^{\prime}$, that would have led to a better outcome, but that given the information available at $t_{1}$, the better alternative could not have been identified. Third, in a final set of cases, it could be that the information available at $t_{1}$ was sufficient to allow the relevant actors to switch from $d$ to $d$ ' based on the undesirable outcome at $t_{2}$. This third form of "path dependency" is sometimes called "remediable path dependency." 24 The first two forms are nonremediable.

\section{The Notion of the Feasible Choice Set}

The idea of a constitutional second best and the distinction between ideal and nonideal theory are related to a more fundamental notion-the feasible choice set. We might think of a variety of choice sets: the set of all conceivable or imaginable choices, the set of all actions that specified actors might choose, and so forth. Of all the conceivable choices that might be made by a specified actor (individual, institutional, or collective) with respect to a given constitutionally relevant situation, some can be called "feasible" and others "infeasible."

The term "feasible" as used in natural language is vague, ambiguous, and context dependent. Feasibility is vague because feasibility can be a matter of degrees, with some choices that are neither clearly feasible nor infeasible. Feasibility is ambiguous because it can refer to possibility, workability, practicality, costliness, or some combination of these. Feasibility is context dependent, because a given action type or action token may be considered practical given one constellation of purpose and available alternative actions, but the same action may be considered impractical given different purposes and alternatives. ${ }^{25}$ For example, constitutional amendment might be considered "feasible" in the context of a particular constitutional problem, say abortion or equal treatment for women, but "infeasible" in the context of another problem, say treatment of billboards under the First Amendment or power of the states to legalize medical uses of marijuana.

Given that "feasibility" is vague, ambiguous, and context dependent, claims that a given constitutional option is inside or outside of the feasible choice set require further specification. At a minimum the criteria for inclusion or exclusion require explicit definition. But once the criteria for inclusion are specified, the idea of a feasible choice set provides a useful heuristic for expressing assumptions about (or conclusions reached) with respect to possibility.

\section{E. Agent Relativity}

Feasibility is a function of both the constitutional option itself and the agent or agents for whom the option is proposed. Constitutional agents range from individual

24. See Pierson, supra note 18 , at 255.

25. An "action type" is a universal, for example, "constitutional amendment" or "reversal of a Supreme Court precedent." An "action token" is a particular, for example, "ratification of the Equal Rights Amendment" or "reversal of Brown v. Board of Education." See Linda Wetzel, Types and Tokens, in STANFORD ENCYClopediA OF PHILOSOPHY, Apr. 28, 2006, http://plato.stanford.edu/entries/types-tokens/ (explaining the type-token distinction). 
citizens and institutional actors (e.g., senators, representatives, presidents, legislators, justices, and judges) to institutions (e.g., Congress, the Supreme Court, the Illinois State Legislature) and collectivities (e.g., We the People of the United States, the Congress and Legislatures of the Fifty States).

A given constitutional option might be infeasible relative to one agent, but feasible relative to another. Ordinarily, constitutional amendments are outside the feasible choice set for ordinary individual citizens: the cases in which an individual citizen can bring about the enactment of a constitutional amendment are rare and even when they exist may be difficult to identify ex ante. Relative to an individual senator, representative, or state legislator, some constitutional amendments may be feasible (because they have sufficient support from others to create a practical possibility of enactment) and others infeasible (because they lack such support). But relative to the collective actor with the power to propose and ratify (Congress and the state legislatures), constitutional amendments are always feasible, because action by this collective agent is legally sufficient to amend the Constitution. Because feasibility is agent relative, a fully specified claim that a given option is inside or outside the feasible choice set must specify the agent. Absent such specification (explicit or implicit), feasibility claims are so ambiguous as to be virtually meaningless.

\section{F. The Scope of Decision Problem}

Agency is related to another dimension of feasibility, which we can call "scope of decision." What does "scope of decision" mean? Sometimes our scope of decision is a single action (an action token), such as the decision by a court in a single case. But not all issues take single actions as their scope of decision.

Consider the following example: constitutional actors (e.g., executive officials, legislators, judges, or courts) may choose whether to employ originalism as the exclusive methodology for (or practice of) constitutional interpretation-as ultimate or final criterion for the correctness of a constitutional interpretation. This decision cannot be made on a case-by-case basis. Why not? This question can be answered via a thought experiment. Suppose you tried to decide in each case whether to deploy originalism as a methodology. How would you make that decision? You might make an ad hoc, all-things-considered judgment in each case whether it would be better to be an originalist or a living constitutionalist. But if you proceeded in that way, then you would already have rejected originalism as the ultimate criterion for decision-because your decision in the particular case would ultimately rest on "all things considered" and not the original public meaning of the constitution. Notice that I am not arguing that one cannot deploy an originalist methodology in some cases and not others. Rather, my point is that a case-by-case decision has a different scope than does a decision that would range across all cases.

In the choice between originalism and living constitutionalism as general methods of interpretation, it's the method or practice (ranging across an action type) and not the individual decision (or action token) that counts. That general methods of constitutional interpretation are practices entails that the scope of decision between such methods cannot be made on a case-by-case basis. These methods compete with ad hoc pragmatism as a universal method. The decision to be an ad hoc pragmatist (selecting textualism, originalism, policy argument, etc. as justifications in each case) has wide or universal scope (within the domain), but given such a method, another decision of narrow scope (case-by-case) must be made. Rather, the decision whether to 
be a consistent originalist or an ad hoc pragmatist has as its scope of decision the whole domain of constitutional decisionmaking. ${ }^{26}$

Scope of decision interacts with the specification of agency. For an individual judge, the decision whether constitutional interpretation should be guided by an originalist methodology is not a feasible choice: one judge (even a very influential Supreme Court Justice) cannot adopt originalism as a methodology for all the members of the federal judiciary. The most that individual judges can do is decide to adopt originalism as a methodology for their own decisions and to attempt to persuade others to do the same. In the short to medium term, the most that could result from such an individual decision is a mixed regime with some originalist and some nonoriginalist decisionmaking. But if the agent is the collectivity of all American judges, then the adoption of an originalist practice for the whole domain of constitutional decisionmaking is within the feasible choice set.

\section{G. A Quick and Dirty Guide to the Metaphysics of Modality}

Few articles on constitutional theory discuss the metaphysics of modality. ${ }^{27}$ Even the terms "modal" and "modality" may be unfamiliar when they are used, as here, to refer to ideas about necessity and possibility-although this usage may evoke a dim recollection that "could" and "must" are called "modal verbs." If unfamiliarity breeds contempt, some readers may be skeptical about the value of a philosophical approach to the modal notions of possibility and necessity for normative constitutional theory. If you are among such readers, know that I shall ask your indulgence for only a page or two.

The primary tool that I shall introduce in this section can be called "possible worlds semantics." Possible worlds talk translates talk about possibility and necessity into talk about possible worlds. Begin with the notion of a possible world. ${ }^{28}$ This notion is similar to the notion of a "state of affairs"-which may be familiar from economics.

26. Of course, the content of the practice need not be "pure originalism" or "pure constitutionalism." For example, there could be a practice of constitutional interpretation that incorporated a default rule favoring originalism, but allowed departures from originalism based on specified criteria. The point is that the scope of the decision to adopt a practice must be larger than the individual case in order for there to be a practice.

27. But see Matthew D. Adler, Popular Constitutionalism and the Rule of Recognition: Whose Practices Ground U.S. Law?, 100 Nw. U. L. REv. 719, 780 (2006); Christopher R. Green, Originalism and the Sense-Reference Distinction, 50 ST. LouIs U. L.J. 555, 566-67 (2006).

28. The idea of possible worlds was introduced by Leibniz. See Gottfried Wilhelm Freiherr von Leibniz, The Theodicy: Abridgement of the Argument Reduced to Syllogistic Form, in Leibniz: Selections 509, 509-11 (Philip P. Weiner ed., 1951). Leibniz used the idea of a possible world in answer to the argument against the existence of good from the problem of evil. See id. at 511 . The argument is not proven, Leibniz maintained, until it is shown that the actual world is not the best of all possible worlds. Id.; see generally JOHN DIVERS, POSSIBLE WORLDS (2002) (providing a comprehensive introduction to possible worlds semantics and the metaphysics of modality); SAUL A. KRIPKE, NAMING AND NECESSITY (1981) (discussing model theoretic study of modal logic "possible worlds" semantics); DAVID LEWIS, ON THE PLURALITY OF WORLDS (1986) (defending modal realism's view that our world is one of many, each with its own inhabitants); Alvin Plantinga, Essays IN the Metaphysics of Modality (Matthew Davidson ed., 2003). 
The philosophical idea of a "possible world" is understood as a complete history of a whole universe. ${ }^{29}$ If some thing is possible, say event $X$, we say that $X$ occurs in some possible world. Complimentary to the concept of possibility is the concept of necessity. Let us say that an event $\mathrm{Y}$ is necessary if $\mathrm{Y}$ occurs in all possible worlds; a proposition, $p$, is a necessary truth if it is true in all possible worlds.

The next step is to add the notion of the "actual world," where actual is an indexical term that separates this world from all possible worlds. ${ }^{30}$ Thus, an actual constitution is a constitution that exists in this world. A possible constitution is a constitution that exists in at least one possible world. A necessary constitution would be a constitution that exists in all possible worlds. Notice that it seems obvious that there are no necessary constitutions as there are possible worlds (including the former states of the actual world) in which there are no constitutions at all. But almost any constitution you can imagine or conceive is surely possible, ${ }^{31}$ because we can posit a possible world in which that imaginable or conceivable constitution exists. ${ }^{32}$ Logical possibility requires only logical consistency, and, in the logical sense, possibility is rarely implicated by debates in normative legal theory.

Not all possible worlds are implicated in debates about constitutional possibility. The constitutional possibilities with which we are concerned exist in a subset of all possible worlds. We can narrow the set of possible worlds that are the domain of constitutional necessity in a series of steps. Each step can be expressed in terms of the idea of an accessibility relation. ${ }^{33}$ The phrase "accessibility relation" may sound obscure, but an example will make it crystal clear. For practical purposes, normative constitutional theory may sometimes only be interested in those worlds that are possible future states of the actual world. Such worlds share the history of the actual world up to this moment, and we call worlds that have this property "historically accessible." Notice that talk about historical accessibility frequently can be translated into talk about "path dependency." The feasible choice set-the future choices that are possible-may be constrained by history.

29. Sometimes, we may refer to a time slice of a world (either a moment or a period with definite or indefinite duration) as a possible world. This can be stated differently: a time slice of one world is itself a distinct possible world-one that comes into being when the time slice begins and expires when the time slice ends.

30. Examples of indexical terms include "I," "here," and "now." See generally David Kaplan, Demonstratives, in THEMES FROM KAPLAN 481 (Joseph Almog et al. eds., 1989).

31. Of course, the description of a constitution could be inconsistent and hence that constitution would not exist in any possible world. The same constitution cannot both include and not include a counterpart to the First Amendment to the United States Constitution. This is not to say that a constitution with contradictory provisions is impossible: of course, the text of the constitution could have conflicting deontic requirements.

32. Philosophers debate the question of whether all possible worlds are real or whether the only real world is the actual world. We shall lay that question aside, and simply talk as if possible worlds were real. Nothing shall hang on this: our investigation of constitutional possibility will be neutral between modal realism and ersatz modal realism. See generally Robert M. Adams, Theories of Actuality, 8 Noûs 211 (1974); Richard B. Miller, Dog Bites Man: A Defence of Modal Realism, 67 Australasian J. PhIL. 476 (1989); Alexander Rosenberg, Is Lewis's 'Genuine Modal Realism' Magical Too?, 98 Mind 411 (1989).

33. See LEWIS, supra note 28 , at 7-8. 
But "historical accessibility" is not a sufficient limitation for the purposes of normative constitutional theory. Why not? Because it is logically possible that the future states of the actual world could be just about anything you can imagine; there is no logical contradiction in a possible world that shares the history of the world up until now but in which the United States instantly becomes a parliamentary democracy at the next snap of Jeremy Waldron's fingers. For the purposes of normative constitutional theory, we should restrict the domain of possible worlds to those that share the basic laws of nature (physics, etc.) with the actual world; these worlds are called "nomologically accessible." 34 In nomologically accessible worlds, Waldron's finger snaps do not produce constitutional revolutions. The historically and nomologically accessible worlds, then, are those that share the history of the actual world up to now and that share our laws of nature.

At this point it is useful to introduce the idea of "distance" between the actual world and some possible world. Adjacent possible worlds are "close" to the actual world. A possible world that was just like the actual world-except that this Essay was never written-would be very close, i.e., adjacent, to the actual world in which the Essay was written for a conference in early December, 2006. Remote worlds are "distant" from the actual world. A possible world in which complete essays appear without effort, simply by snapping one's fingers would be more remote. Even more distant worlds are easy to imagine. In ascending degree of remoteness, we can imagine a world in which the Mongols conquered Europe and the Renaissance did not occur, a world in which humans never evolved, or a world in which subtle variations in physical laws made the evolution of carbon-based life impossible.

The constitutional possibilities that concern normative constitutional theory are primarily those that exist in historically and nomologically accessible possible worlds that are adjacent to the actual world. ${ }^{35}$ One set of accessibility relationships is especially relevant to constitutional discourse: these relationships concern human psychology, institutional capacities, social norms, and political attitudes. Some constitutional options will not work, given what is true about human psychology-they make unrealistic assumptions about what officials or citizens are capable of doing. Other constitutional options would require dramatic changes in social norms-their success relies on unrealistic assumptions about what citizens and officials believe is acceptable or unacceptable conduct. Some options make counterfactual assumptions about institutional capacities. And yet other constitutional options are politically infeasible-they presuppose political attitudes that only exist in possible worlds that are remote from the actual world. But normative constitutional discourse requires what we might call "normative space." That is, normative discourse assumes that minds can be changed and the attitudes are not entirely fixed. We can call worlds that conform to

34. Id. at 20.

35. For some purposes, however, constitutional theory may wish to investigate questions of alternative constitutional history. These are "what if" questions. What if Brown v. Board of Education had been decided the other way? What if The Slaughterhouse Cases hadn't nullified the Privileges and Immunities Clause of the Fourteenth Amendment? What if President Roosevelt had chosen the path of constitutional amendment rather than transformational appointment to implement the New Deal's constitutional program? In each case, we imagine a nomologically accessible possible world that was historically accessible from a prior state of the actual world. 
the laws of psychology and political science but in which attitudes and beliefs are not fixed "psychologically and politically accessible worlds."

Sometimes normative constitutional theory has practical aims-it is concerned with how we should act in the actual world. Let us call constitutional action in the actual world "constitutional practice." ${ }^{36}$ Constitutional practice is not concerned with historically and nomologically accessible possible worlds that cannot come into being given the limits on human choices. If there is nothing that any agent (individual, institutional, or collective) does in any historically and nomologically accessible world that brings a future state of the world about, then the future state is outside the feasible choice set. Let us call the worlds that are open to human choice in the sense just specified "practically accessible." A practically accessible world must be nomologically and historically accessible through human agency. "Constitutional practice" is, by stipulation, concerned with possible worlds that are "practically accessible."

One final accessibility relation requires a brief mention. We can distinguish between those worlds that are consistent with our knowledge of the actual world and those which are inconsistent with such knowledge. We can use the phrase "epistemologically accessible" to capture this idea. Worlds that are consistent with everything we know about the actual world are epistemologically accessible. Worlds that have a feature contradicted by our knowledge of the actual world are epistemologically inaccessible. Not all epistemologically accessible worlds are nomologically and historically accessible; there may be historical facts or natural laws of which we are unaware.

We are now in a position to revisit the idea of a feasible choice set. A claim that a given constitutional option is outside the feasible choice set is a claim about constitutional practice, and hence a claim about which possible worlds are practically accessible. Usually, a claim that a given constitutional option is infeasible will rest (either explicitly or implicitly) on a claim about human psychology, anthropology, economics, sociology, or political science.

For example, the claim that a constitutional amendment banning abortion is politically infeasible, if fully articulated, would rest on claims: (i) about the legal requirements for constitutional amendments, (ii) about beliefs and desires causally relevant to the motivations of constitutional actors such as congresspersons and state legislators, and (iii) about the beliefs and desires of citizens. Thus, the claim might be that, given the legal requirements, the motives of those whose assent is legally required for a constitutional amendment, and the attitudes of voters, a constitutional amendment banning abortion is impossible. In possible worlds talk, we might say that worlds in which such amendments become law are relatively remote from our own; in these worlds, political actors behave much differently or many citizens have different attitudes about abortion or the legal requirements for a constitutional amendment have been altered. This remoteness is the underlying reason for our judgment that such a constitutional amendment is outside the feasible choice set.

Constitutional options that exist only in possible worlds that are either historically or nomologically inaccessible are outside the feasible choice set in a very strong sense. They cannot come about in a future state of the actual world given the natural laws that

36. This is a stipulated usage. The phrase "constitutional practice" could be used in a variety of other senses. 
govern this world. Constitutional options that exist in historically and nomologically accessible worlds may nonetheless be only remote possibilities - they may depend on changes in beliefs, desires, or institutions that depend on unlikely contingencies. When such possibilities are sufficiently remote, we may say they are outside the feasible choice set-but if we speak in this way, we are using "feasibility" in a sense that diverges from historical and nomological possibility.

At this point, skeptics might ask what value possible worlds semantics adds to constitutional theory. One answer to this question distinguishes between value that is added "behind the scenes" and value that is added "on stage." It seems to me unlikely that explicit discussion of possible worlds semantics will be required, except in the rarest of circumstances. One can certainly imagine that constitutional theory informed by possible worlds semantics might explicitly deploy phrases like "psychologically impossible" or "outside the politically feasible choice set." In such cases, the work done by possible worlds talk would be "behind the scenes"- the ideas can be expressed without elaborate philosophical machinery. Indeed, in most cases one can imagine clarity and precision with any explicit use of the philosophical machineryeven "behind the scenes." All that is really required is explicit awareness of the distinctions between the various reasons for impossibility and the explicit incorporation of these distinctions in the expression of possibility and impossibility claims.

The role of possible worlds semantics, then, is likely to be limited to the rare case in which there is a need for a theoretical framework that allows complex, ambiguous, or vague claims about possibility and impossibility to be made fully explicit. One can imagine that constitutional theorists might invent such a framework "on the spot," so to speak. Or we can imagine that possible worlds semantics would provide a "ready to hand" set of devices and distinctions that would enable theorizing about constitutional possibility to gain maximum clarity and precision with a minimum of intellectual effort.

\section{H. A Very Short Introduction to Positive Constitutional Theory}

So far, the investigation of constitutional possibility has been entirely conceptual. But claims about which options are inside or outside of the feasible choice set are claims in positive constitutional theory; that is, they are claims about the beliefs, desires, and attitudes as well as the laws of human psychology, sociology, and political science that govern those human actions that enable constitutional possibilities. The social and human sciences are, of course, a vast topic-even for a very short introduction. Nonetheless, a very brief mapping of the territory is possible.

We can begin with the dominant (and allegedly most successful) tool for the explanation of human and social behavior, which at a very high level of abstraction can be called "rational choice theory." 37 The basic assumption of rational choice theory is that individual humans act rationally-where rationality is defined in terms of the relationship between beliefs, desires, and actions. An action is rational if it is action

37. See, e.g., RATIONAL CHOICE (Jon Elster ed., 1986) (collecting essays on rational choice as a methodology for the social sciences). But see Donald P. GREEN \& IAN SHAPIRo, Pathologies of Rational CHOICE Theory: A CRITIQUe of APPLICATIONS IN POLITICAL SCIENCE (1996). 
that would satisfy the agent's desires (or preferences) given the agent's beliefs (the information available to the agent). The most familiar example of rational choice theory is neoclassical microeconomics, and another important form is game theory. ${ }^{38}$

As applied to the political domain, rational choice theory is expressed as "positive political theory" and "public choice theory." 39 For example, the question whether a given constitutional amendment could pass (or a nominee for the Supreme Court could be confirmed) can be addressed via a formal model of voting behavior in the House, the Senate, and the various state legislatures. ${ }^{40}$ Such a model might assume that each member of these legislative bodies has a set of policy preferences that can be expressed as a position on a real line (from right to left) in ideological space. Whether a statute will pass depends on the median voter in the legislature-since the majority rule makes the vote of the legislator who occupies the median position on the ideology line the critical vote. Similarly, whether a given constitutional amendment would pass could depend on whether the critical voter in the House, the Senate, and the critical voter in all houses of legislatures constituting two-thirds of the total number of states, would view the state of affairs that would obtain after the amendment was passed (represented as a point on the ideology line) as an improvement over the status quo (also represented as a point on the line). This model might be grounded in a more basic explanation of legislator behavior in terms of their preferences for gaining and retaining office - or by some other model of rational action by legislators. Typically, rational choice theories (including positive political theory and public choice theory) are expressed in formal models, although such models may also be explicated informally or through precise analysis of the conceptual content of the claims made by the models.

Rational choice theory has rivals and variants. For example, recent work in behavioral economics emphasizes cognitive mechanisms that may produce behavior that traditional rational choice theory would label irrational. ${ }^{41}$ Another approach emphasizes the role of causal mechanisms or microfoundations in the social sciences. ${ }^{42}$ One strand of the sociological tradition emphasizes the functional role that institutions and other social phenomena may play in producing social stability or cohesion. Marxist explanations might describe the limits on constitutional possibility in terms of the functional role of law in relationship to class interests. ${ }^{43}$ Less formally, the limits of constitutional possibility might be described by stories or historical narratives that

38. See, e.g., DREW FUdENBERG \& JEAN TIROLE, GAME THEORY (1991).

39. See generally William H. RIKER \& P.C. ORderSNOOK, INTROduCtion to POSITIVE POLITICAL THEORY (1972) (discussing positive political theory). For a discussion of public choice theory, there are several good choices available. See generally DUNCAN BLACK, THE THEORY OF COMMITTEES AND ElECTIONS (1958); JAMES M. BuCHANAN \& GORDON TULlOCK, The CalCulus of CONSENT (1962); MANCUR Olson, JR., The Logic of COllective ACtion (1965).

40. See David S. Law \& Lawrence B. Solum, Judicial Selection, Appointments Gridlock, and the Nuclear Option, 15 J. CONTEMP. LEGAL IsSUES 51 (2006).

41. See, e.g., BEHAVIORAL LAW AND ECONOMICs (Cass R. Sunstein ed., 2000); JUdGMENT UNDER UNCERTAINTY: HEURISTICS AND BIASES (Daniel Kahneman et al. eds., 1982).

42. See, e.g., SOCIAL MECHANISMS: AN ANALYTICAL APPROACH TO SOCIAL THEORY (Peter Hedström \& Richard Swedberg eds., 1998); JON ELSTER, NUTS AND BOLTS FOR THE SOCIAL SCIENCES (1989).

43. See G.A. COHEn, KarL MARX's Theory of History: A DefenCE (1992). 
identify the motives and beliefs of particular constitutional actors or groups of such actors. Comparative constitutionalism and constitutional history offer additional tools; constitutional possibilities may be established by pointing to constitutional models in other societies or in our own history.

Social science can provide the tools for systematic and rigorous discussion of constitutional possibility in the service of normative constitutional theory, but such tools might be deployed in various ways to undermine or criticize normativity. In an extreme form, rational choice theory or its alternatives can be deployed in a reductionist or eliminativist program. That is, normative constitutional theory can itself be explained as rational, self-interested behavior or as an ideology that serves the interests of the ruling class. ${ }^{44}$ The most extreme version of such reductionism might characterize normative constitutional theory as mere "cheap talk" or as the post hoc rationalization of constitutional politics that is driven entirely by interests or forces outside the realm of normative theory. Positive constitutional theory might swallow normativity in another way, by making claims about constitutional determinism-the thesis that constitutional actors lack "free will" and hence that our constitutional fate is preordained.

As a practical matter, normative constitutional theory assumes the viability of libertarian or compatabilist views about constitutional choice. ${ }^{45}$ The intellectual division of labor among these disciplines assumes that normative constitutional theorists are entitled to get on with the business of evaluating constitutional choices; the deep questions posed by reductionism and determinism are properly deferred to other disciplines, theorists, and occasions.

The point of this brief survey of positive constitutional theory is simply to suggest constitutional theorists can access a wide variety of tools for arguing about constitutional possibility. These tools range from the formal, game-theoretic work of positive political theorists to the informal, narrative, and historical efforts of new institutionalists. All of these approaches provide models for developing claims about constitutional possibilities that go beyond hand waving and mere assertion.

\section{Why a Toolkit and Not a Theory?}

We need to address (albeit briefly) another set of issues before we move on. Why provide a toolkit for thinking about constitutionality possibility and not a theory of constitutional possibility? Would the systematic and conceptual unity of a theory provide a surer cure for the ills of confusion, ambiguity, and inconsistency?

Perhaps, but there are at least two reasons for offering a toolkit rather than a theory. The first reason is that the topics of feasibility and possibility are relatively unexplored in legal theory in general and constitutional theory in particular. A theory produced after the issues have been made explicit and digested seems more likely to have lasting value than would a theory introduced at such an early stage of development. The second reason for preferring a toolkit to a theory is that it is at least "possible" that a

44. For an illuminating discussion, see generally Brian Leiter, Morality Critics, in THE OXford HandBook of ConTINENTAL PhILOSOPhy (Brian Leiter \& M. Rosen eds., 2007).

45. David DENNETT, Elbow RoOM: VARIETIES OF FreE WILl WORTH WANTING (1984); Michael McKenna, Compatibilism, in STANFORd ENCYCLOPEDIA OF PHILOSOPHY, Apr. 26, 2004, http://plato.stanford.edu/entries/compatibilism/. 
toolkit is all we need. Thinking about legal or constitutional possibilities may not require an elaborate theory that applies to the entire range of modal issues in constitutional discourse. For example, possible worlds semantics may illuminate a few thorny problems but simply not be worth the intellectual overhead for most discussions of constitutional possibility. In some contexts, we might be fully satisfied with the idea of constitutional second best combined with a careful explanation of what variable is constrained and why. In other contexts, it might be the distinction between ideal and nonideal theory that would do the required work. For both reasons, this essay eschews a general theory and offers instead a toolkit.

\section{AVOIDING THREE CONCEPTUAL ERRORS}

With our conceptual toolkit in place, we can now examine three fundamental errors that might confuse our thinking about possibility. The first error is to reduce possibility to cost. The second error is to infer that the conceivability of a choice or outcome entails its practical possibility. The third error is to equate possibility with probability. Each of these errors can and should be avoided.

\section{A. The Error of Reducing Possibility to Cost}

Positive and normative law and economics provide powerful frameworks for thinking about the law and policy. Part of that power derives from a focus on costs and benefits. Frequently, we can understand and predict behavior by focusing on the expected costs and benefits of alternative actions. Sometimes, the action that is morally best is the action that accrues the greatest benefits or minimizes costs. If carried to an extreme, this focus on costs and benefits might lead to the conclusion that talk about possibility and feasibility can be reduced to talk about costs. We might come to believe that the sentence, "Outcome A is impossible," can be reduced to, "Outcome A is too costly to be seriously considered." Or "Choice B is not feasible," might be equivalent to "Choice B is so costly that it should not be considered as an alternative."

Possibility cannot be reduced to cost for several reasons. First, some kinds of impossibility are unrelated to cost (in even the broadest sense of that term). The number of Senators apportioned to each state cannot simultaneously be equal and proportionate to population; given unequal population size, this would be a logical impossibility. Second, the attribution of costs to options is dependent upon a prior notion of possibility. Thus, if we say that option A entails the accrual of cost $n$, that assertion depends on the prior assumption that a state of affairs in which option $A$ is chosen, but cost $\mathbf{n}$ is not accrued is not a possible state. Third, even when costs play a causal role in establishing impossibility, agent relativity differentiates between costs as factors to be weighed in decisionmaking and costs that make certain outcomes practically impossible. For example, if respecting the freedom of speech is costly in cases involving advocacy of terrorism, the Supreme Court (as a relevant constitutional agent) might take that fact into account. And in some circumstances, high costs might lead the court to view a given constitutional rule as "infeasible." But this is quite different from the court reaching the conclusion that compliance with a rule would be impossible, because the costs associated with compliance would be too large for the affected governmental entity to bear. In the first case, the costs are factors to be weighed in making the decision. In the second case, the costs are causal influences that determine which outcomes are possible from the point of view of the Court. 


\section{B. The Error of Inferring Practical Possibility from Conceivability}

The relationship between conceivability and possibility is complex and much debated, ${ }^{46}$ but for the purposes of normative legal theory the important question concerns the relationship between conceivability and practical possibility. Sometimes, impossibility assertions are cast in terms of inconceivability. For example, one might say, "It is inconceivable that the United States Supreme Court would overrule Brown v. Board of Education." 47 In some cases, inconceivability does imply practical impossibility. If none of the Supreme Court Justices can imagine overruling Brown $v$. Board and if the action must be conceived as a possibility before it can be performed, then inconceivability entails a certain kind of impossibility. The action is impossible until it is imagined; it then becomes possible in the sense that it is "on the table" or "open for discussion." But it is a mistake to run the inference in the opposite direction. Conceivability does not entail practical possibility. That is because, practical possibility is always contingent upon a variety of factors that are not causally dependent upon conceivability. For example, a Supreme Court Justice might have imagined that the Court's decision in Brown $v$. Board would have resulted in immediate compliance, but imagining would neither make it so nor make it practically possible for it to be so.

The point of this discussion is that conceivability and practical possibility may be related, but they are not identical. When both matter to a particular discussion, each should be analyzed on its own terms and the relationship between the two concepts should be made explicit.

\section{The Error of Equating Possibility and Probability}

Another tempting error is to equate possibility and probability. Possibility is normally understood as a binary function. An action, outcome, or event is either possible or impossible-once we specify the "sense of possibility" or, more technically, the accessibility relationships that define the relevant set of possible worlds. Probability, however, is a scalar: a given outcome may be "more or less likely" or, more formally, its probability may assume any real value from 0 to 1 . The tempting mistake is to equate "possible" with "probability greater than zero" and "impossible" with "probability equal to zero." Given this move, an even more serious error becomes tempting: one might then say that assertions of "impossibility" are actually assertions of "extreme improbability," with the consequence that the concept of impossibility would turn out to be confused or mistaken.

But the equation of possibility and probability is, in fact, based on conceptual confusion. The nature of the error is easiest to see in the case of logical possibility. It simply does not make sense to assert that it is merely improbable that the following two statements are both true: (1) this article was written entirely in the twenty-first century, and (2) this article was not written entirely in the twenty-first century. It is

46. See Conceivability and Possibility (Tamar Szabó Gendler \& John Hawthom eds., 2002).

47. 347 U.S. 483 (1954); see Henry Paul Monaghan, Stare Decisis and Constitutional Adjudication, 88 COLUM. L. REV. 723, 744-45 (1988). 
logically impossible that both statements are true, and the concept of improbability has no application to this kind of case. If someone were to assert the following: "The probability of both statements being true is zero," we would understand that they were using probability in a figurative or metaphorical sense. There may be cases where "impossible" means "probability of zero," but not all cases are like this. In some cases, talk of probabilities is simply inappropriate.

\section{IMPLICATIONS OF CONSTITUTIONAL POSSIBILITIES}

What are the implications of a richer understanding of constitutional possibility for constitutional theory and practice? This question can be answered in two different ways. First, we can examine the general implications of constitutional possibility for normative theory, and second, we can formulate standards for making sound arguments about constitutional possibilities and necessities.

\section{A. Implications for Normative Constitutional Theory}

A systematic investigation of constitutional possibility has some direct implications for normative constitutional theory. Let's begin with the most basic point—ought implies can.

\section{Ought Implies Can and the Possibility of Collective Action}

The maxim "ought implies can" is associated with Immanuel Kant, ${ }^{48}$ and according to one interpretation the maxim authorizes an inference from an "ought proposition" (expressing an obligation) to a modal assertion that it is possible to do the action which ought to be done. The conventional understanding interprets the "implies" in "ought implies can" to mean that "if a given action, $x$, is not possible, then that action is not obligatory." "Thus, no one can be obligated to do the impossible: humans are not obligated to perform miracles. Of course, whether "ought" does, in fact, imply "can" will depend on what we mean by "ought" and in what sense we mean "can." Consider the following: "I am not obligated to do my duty to keep my promise, because I simply cannot bring myself to do anything unpleasant." Inability in that sense is not excusing.

In context, the idea is that our practical constitutional obligations are constrained by our practical constitutional possibilities. At that level of abstraction, "constitutional ought implies constitutional can," is likely to gain wide assent. But agreement is likely to break down once problems of cooperation and group versus individual agency are introduced. Are we obligated to lend our support to just efforts to amend a wicked constitution, even if we believe that such attempts are doomed to fail? And this question is different than the question whether we are obligated to amend a wicked

48. Immanuel Kant, Critique of Practical Reason, in Practical PhILOSOPHY 30 (Mary J. Gregor ed. \& trans., 1996); see also STEPHEN DARWALl, THE SECOND-PERSON STANDPOINT: MORALITY, RESPECT, AND ACCOUNTABILITY 33 (2006); Paul Guyer, Immanuel Kant (17241804): Freedom of the Will and the Highest Good, in ROUTLEDGE ENCYCLOPEDIA OF PHILOSOPHY, Feb. 29, 2004, http://www.rep.routledge.com/article/DB047SECT11.

49. $\mathrm{O}(\mathrm{x}) \rightarrow \mathrm{P}(\mathrm{x}) \leftrightarrow \neg \mathrm{P}(\mathrm{x}) \rightarrow \neg \mathrm{O}(\mathrm{x})$, which can be parsed as " $\mathrm{x}$ is obligatory implies that $\mathrm{x}$ is possible if and only if $\mathrm{x}$ is not possible implies that $\mathrm{x}$ is not obligatory." 
constitution when we have no power or means to do so. And both of these questions are different from a third: do we have an obligation to vote for an amendment to a wicked constitution that is before us, even though we know that the amendment will not pass?

Consider the following hypothetical example: suppose that there is a historically and nomologically accessible world with a better constitution for the United States-a constitution without equal suffrage for the states, without an electoral college, with provisions for the removal of incompetent presidents and judges, and so forth. Relative to some collective agent (e.g., "We the People" or "Congress and the state legislatures"), radical constitutional change is a practical possibility. Assume that relative to any individual agent, extensive revision or replacement of the Constitution is a practical impossibility. Hypothetically, nothing that I can do will bring about a constitutional amendment - and therefore (it could be argued), I have no obligation of political morality even to attempt to bring about such a change: in historically and nomologically accessible possible worlds, my attempt will be futile. In the hypothesized scenario, even the most powerful individual actors (e.g., the Speaker of the House or the Senate Majority Leader) cannot act so as to create a significant probability that a constitutional amendment would actually become law. ${ }^{50}$

What are our constitutional obligations given this hypothetical (but not unrealistic) case? The hypothetical assumes that we can attempt constitutional reform, but our attempt cannot (or with an overwhelming probability, will not) succeed. Does the impossibility of success excuse participation in the movement for reform? If impossibility excuses, what about improbability? The point of raising these questions is to expose the ambiguities and disagreements that lie behind assent to the abstract proposition that ought implies can.

These issues are deep ones, and similar issues are familiar from debates in moral theory. ${ }^{51}$ If they are resolvable, this is not the occasion for their resolution. The very modest point of raising them is to emphasize the need for normative constitutional theory to be clear about agency and possibility in making claims about constitutional obligation. Claims that the existing constitutional order falls short of the constitution of ideal theory are one thing; claims that individuals or institutions have violated an obligation of political morality by failing to cooperate in a program of constitutional reform or revolution are another.

To the extent that arguments within normative constitutional theory implicitly rest on "ought implies can," clarity may require specification of two things: (1) the identity

50. There may be "critical junctures" at which individual action would become obligatory. See generally RUTH Berins Collier \& David CollieR, SHAPING the Political ARENA (2d ed. 2002) (explaining the idea of "critical juncture").

51. For example, rule-utilitarians and act-utilitarians may disagree over the obligations to perform actions that will not be effective given that, in the actual world, others may not cooperate in the creation of a good or the avoidance of an evil. Act-consequentialism makes the rightness of an action dependent on the consequences of the individual action, whereas ideal rule-consequentialism focuses on the consequences of actual compliance with a system of rules. See generally BRAD HOOKER, IDEAL CODE, REAL WORLD (2000) (articulating ruleconsequentialism and contrasting it with act-consequentialism). Similarly, deontological moral theories may prohibit actions that violate the moral rights of others, even if the consequence of a given agent refraining from the prohibited action is that some other person will commit the wrong. 
of the agents addressed by the arguments, and (2) the underlying theory of the political morality of individual action that requires cooperation for efficacy. The alternative to this kind of specificity is to invite confusion and misunderstanding.

\section{Ideal Theory Distinguished from Bad Utopianism}

Ideal theory has an important role to play in normative constitutional theory. Ideal theory is arguably part of an intrinsically valuable activity - the discovery of normative truths - even if that activity does not or cannot change constitutional practice. Moreover, ideal theory may provide ideas, arguments, and standards that are relevant to nonideal theory. For example, it might be the case that the constitution of ideal theory would provide the telos, or goal, that constitutional practice should strive to achieve.

But ideal theory should be distinguished from what might be called "bad utopianism"- $a$ theoretical practice that relies on false assumptions about human nature or institutional capacities in order to argue for constitutional arrangements that exist only in nomologically inaccessible worlds. Recall that in the Rawlsian sense, ideal theory makes idealizing assumptions about compliance, but it does not make counterfactual assumptions about the limits of human or institutional capacities. This is not to say that a given ideal theory could not exemplify bad utopianism. For example, a normative constitutional theory might seek to establish the practical normative significance of an ideal constitution, but fail to acknowledge that the ideal's attractiveness rested on an assumption of perfect compliance that is inconsistent with actual human nature - an example of what I call "bad utopianism." 52

3. The Best of All Possible Constitutions, Comparative Constitutionalism, and Constitutional Second Bests

The question whether either ideal theory or a constitutional model exemplified in another society should provide the normative standard for actual constitutional practice is strongly connected to the ideas about path dependency and the constitutional second best. Consider two ideas: (1) because of path dependency, constitutional comparisons are insufficient to establish practical possibility, and (2) the constitutional second best may not be the closest approximation to the best of all possible constitutions. These two ideas can be fleshed out in the context of an example-the case for parliamentary democracy as a constitutional ideal.

Let's suppose for the sake of argument that the best of all possible constitutions would be a parliamentary democracy with an institutional structure that approximates that which exists in the United Kingdom - but without a dodgy royal family. The case for this constitution might rest on the idea that democratic governance is justified by

52. This is not to say that something similar to "bad utopianism" could never play a constructive role in normative constitutional theory. By making wildly implausible or counterfactual assumptions about human nature, we might illuminate the underlying reasons for certain normative conclusions. For example, we might assume executive perfection and argue that given that assumption, there would be no need for a constitutional requirement of due process. That thought experiment might then illuminate why due process is required in the actual world. 
considerations of equality and deliberative autonomy and that the parliamentary form does the best job of protecting these basic liberties. From the premise that parliamentary democracy is first best, one might argue that incremental changes in the actual Constitution of the United States should move constitutional practice in the direction of this model. For example, it might be argued that the direct election of Senators (as provided by the Seventeenth Amendment) was justified, because it moved the United States Constitution in the direction of the parliamentary model. ${ }^{53}$ The "real world" feasibility and desirability of the parliamentary model might be established by comparative constitutional analysis - pointing to the United Kingdom and other parliamentary democracies as models.

But granting the premise that parliamentary democracy is the key feature of the best of all possible constitutions and that comparative analysis establishes its feasibility, it does not follow that incremental changes that move in the direction of the parliamentary model are normatively justified. First, it is not necessarily the case that the feasible choice set includes the establishment of a parliamentary democracy in the United States-except in the very long run or in the cases of a catastrophic constitutional crisis. For example, it might be the case that no constitutional amendment abolishing equal suffrage of the States in the Senate could gain the assent of three-quarters of the state legislatures; moreover, Article $\mathrm{V}$ of the Constitution purports to insulate equal suffrage in the Senate from change by amendment. ${ }^{54}$ If parliamentary democracy is outside the feasible choice set, then moves in that direction cannot be justified as steps on the path towards the ideal. Second, it is not necessarily the case that the constitutional second best for the United States is the closest possible approximation of parliamentary democracy. The constitutional second best might be even more distant from parliamentary democracy than the status quo: for example, it is conceivable that more vigorous judicial supervision of policy would counteract the Senate's anti-majoritarian structure in ways that systematically produced better outcomes than the more "parliamentary" alternative-a highly deferential practice of judicial review.

\section{B. Standards for Modal Constitutional Arguments}

"Modal constitutional arguments" are arguments about constitutional possibilitiesabout what constitutional actions and events are possible or necessary. What are the implications of our investigation of constitutional possibility for sound arguments of this sort?

\section{The Criteria for Modal Claims Should Be Articulated}

Claims about constitutional possibility and necessity are ambiguous. For example, the claim that a given constitutional action or event is "impossible" is almost never a claim about logical possibility, but the precise nature of the modal claim is rarely specified. When that lacuna is combined with a failure to specify the relevant agent and scope of decision, there is a good chance of misunderstanding and confusion.

53. U.S. CONST. amend. XVII; see also United States Senate, Direct Election of Senators, http://www.senate.gov/artandhistory/history/common/briefing/Direct_Election_Senators.htm.

54. U.S. CONST. art. V. 
The remedy is the articulation of criteria for modal claims. In what sense is a given constitutional action or event possible or impossible, feasible or infeasible? In particular, it is important for constitutional impossibility claims to make it clear whether the claim is based on path dependency (historical accessibility), facts about human nature or institutional capacity (nomological accessibility), or the existing attitudes, beliefs, and desires of constitutionally relevant agents.

Meeting the articulation standard will require more precision than is usually found in contemporary constitutional theory and practice, but it does not require any particular vocabulary. Possible worlds semantics provides a convenient and precise vocabulary, but the resources of ordinary English provide sufficient resources for full articulation of claims about the possibility or impossibility of constitutional options. All that is required is that modal claims be stated in locutions like "This is impossible in the sense that ..." or "The practicality possibility of this proposal depends on ...."

\section{The Evidence for Impossibility Claims Should Be Stated}

Claims about constitutional possibility are sometimes made without supporting evidence. Of course, claims that a given constitutional option is either possible or impossible do not always require evidence-some things are obvious and uncontroversial. But when a normative constitutional claim rests on the assertion that an alternative option is impossible or infeasible, discourse will be improved if evidence for the assertion is made explicit. Once the evidence is on the table, it is subject to scrutiny and possible refutation. Moreover, there is no general or a priori reason to believe that impossibility claims do not require evidence. And the claim that a given constitutional option is outside the feasible choice set may turn out to be controversial and contestable.

\section{Double Standards Should Be Avoided}

Finally and importantly, arguments about constitutional possibility should avoid double standards. That is, if one argues against a constitutional alternative on the ground that it is outside the feasible choice set, then one is obligated to show that the preferred option or options are inside the set-on the basis of the same criteria and in light of available evidence.

The possibility of a constitutional double standard can be illustrated by reference to a hypothetical dispute between advocates of constitutional originalism and Dworkin's view of law as integrity. ${ }^{55}$ Originalists might claim that their approach is superior because it provides objective standards for correct constitutional interpretation. A Dworkinian might attempt to refute this claim by arguing actual judges are incapable of discerning the original public meaning of the Constitution; in the actual world, the argument might go, judges and justices lack both the historical chops and the capacity to set aside their own preferences. But if the Dworkinian (or quasi-Dworkinian) were then to appeal to Dworkin's ideal judge, Hercules, when the feasibility of law as integrity was assessed, a double standard would have been imposed. ${ }^{56}$ In the actual

55. See generally RONALD DWORKIN, LAW's EMPIRE (1986).

56. The example is illustrative and not intended as a criticism of Dworkin himself. Dworkin knows that Hercules is an idealization and not a role model. 
world, the same judges who lack historical chops may lack Hercules's capacity to construct the theory that best fits and justifies the law as a whole; in the actual world, the same biases that distort originalist judges could distort the method of law as integrity. Of course, we can easily imagine that the tables are turned and that it is the originalists who deploy a double standard.

\section{Two CaSe StUdies IN CONSTITUTIONAL PossibILITY}

\section{A. Levinson on Structural Constitutional Reform}

In his recent book, Our Undemocratic Constitution, Sandy Levinson argues that the United States Constitution suffers from grievous structural defects. ${ }^{57}$ These defects include: (1) the allocation of power to the Senate in which representatives of a substantial minority of citizens hold a majority of votes; (2) the very high probability that a presidential dictatorship would follow a catastrophic attack on members of Congress; (3) too much power for the President; (4) the Electoral College, which permits the election of Presidents by a minority of voters; (5) the long period that lame duck Presidents and Congresses serve; (6) the limitation of impeachment to high crimes and misdemeanors and the absence of a mechanism for removal of the President on grounds of incompetency; (7) the functional impossibility of constitutional amendment. ${ }^{58}$ But are solutions to these grievous ills possible? This question has special urgency because Levinson's indictment of Article V rests fundamentally on the claim that constitutional amendments are functionally impossible.

One of the most interesting features of Levinson's indictment of "our undemocratic Constitution" is the role that modal claims play in his argument. In an important sense, the "functional impossibility" of amending the Constitution through Article V is an essential assumption for all of the constitutional failures that Levinson identifies. If Article $V$ were adequately responsive to democratic pressures, then the other problems could be fixed, but given the "functional impossibility of amendment," changes to fix grievous flaws (such as the continuity of government problem) face enormous obstacles-even though no entrenched political interests would be threatened.

Levinson's idea of "functional impossibility" is not theorized, but it is possible to reconstruct his argument. The relevant agent to whom the functional impossibility claim applies is something like "a national democratic majority." The agent is a majority, because Levinson is explicitly worried about the inability of majorities to amend the Constitution. The agent is not "We the People" as a collectivity, because supermajorities can amend the Constitution. What accessibility relationships would cash out Levinson's "functional impossibility"? It seems clear that Levinson is dealing with historically and nomologically accessible possible worlds; and that his notion of what is "functionally possible" is based on an implicit positive theory about the attitudes and beliefs that motivate the constitutional actors who are formally empowered to propose and ratify constitutional amendments.

Levinson argues that some of the Constitution's defects can be corrected through constitutional amendments passed through ordinary political processes; for example, the problem of continuity in government in the event of a catastrophic attack on

57. LEVINSON, supra note 4 , at 167.

58. Id. 
Congress could be corrected by a constitutional amendment that could garner the support of current or future members of Congress and state legislatures. ${ }^{59}$ This portion of his argument is based on the idea that some amendments are difficult but not impossible.

When it comes to the most significant structural defects-for example, the equal suffrage of large and small states in the Senate, Levinson is quite frank that remedies through ordinary political mechanisms are infeasible. As Levinson puts it, "It may seem almost frivolous to suggest ordinary politics is the way to correct these defects." ${ }^{60}$ Even if Senators from large states attempted to form a coalition that would lobby for a constitutional amendment, the incentives provided by the institutional structure of the Senate would provide powerful incentives for logrolling as usual. ${ }^{61}$ In other words, Levinson does a very credible job of articulating the criteria for feasibility, providing evidence for his claims, and he explicitly acknowledges the need to avoid double standards. ${ }^{62}$

So what is the solution? Again, Levinson's frankness is admirable - he is adamant that his suggestions be treated as the start of a conversation and not as definitive answers to the problem of constitutional possibility. ${ }^{63}$ The core of his tentative suggestion is collective action by individual citizens, starting with conversations among friends and neighbors, progressing to grass roots organizing, and proceeding to a petition drive for a new constitutional convention. ${ }^{64}$ If petitions directed at Congress fail, Levinson suggests citizen lobbying of state legislatures - triggering the Article V procedure for calling a constitutional convention in response to a petition from twothirds of the state legislatures. ${ }^{65}$

What are we to make of this proposal? Is a mass movement for wholesale constitutional reform really feasible? Of course, there is one sense in which it is obvious that such a movement is feasible. The collective agent that consists of "We the People," the citizenry of the United States, could engage in the actions that Levinson describes. But Levinson cannot consistently focus on this collective agent as the solution to his problem. Why not? Because for "We the People," Article V does not make constitutional amendments a "functional impossibility." If "We the People" are the relevant agent, then constitutional amendments are within the feasible choice set. So, Levinson cannot appeal to collective agency as the solution to the problem of constitutional possibility without employing a double standard.

In order to avoid a double standard of constitutional possibility, Levinson can (and seemingly does) appeal to citizens as individuals. Implicitly, Levinson seems to make the (seemingly plausible) assumption that the structural defects in the Constitution are sufficiently serious that they could motivate many individuals to act. Thus, he suggests that individual citizens might purchase and share his book as a very preliminary step towards the creation of a mass movement. But this solution has obvious problemsproblems of collective action that are familiar to economists and political scientists.

59. Id. at $168-69$.

60. Id. at 169 .

61. Id. at $171-72$.

62. Id. at 171 ("Given the central thesis of this book, it would be almost self-contradictory to say that the remedy to our most basic ills lies in ordinary politics.").

63. Id. at 172 .

64. Id. at $172-73$.

65. Id. at $173-74$. 
One way to frame the collective action problem that Levinson's solution faces is to ask the following question: do I have an obligation of political morality to participate in such a movement? The structure of the choice situation is conventionally captured by the game theoretic analysis of prisoner's dilemmas and free rider problems. Let's take a very simple version of the problem. Suppose that I have two options. Option one is to join the democratic constitution movement in its current early and informal phase by purchasing and distributing several copies of Levinson's book, participating in meetings about its ideas, and writing letters to my Senators and Representatives urging them to introduce and support several constitutional amendments. Option two is to expend these resources on another project (which might be efforts in support of the Global Fund and Oxfam but could just as well be writing a book or reading a few dozen novels). Suppose that I reason as follows: if there is sufficient political support for Levinson's program, then my efforts have a vanishingly small chance of making the difference between success and failure, but if there isn't sufficient political support, then my efforts will be ineffectual. In either case, I will incur significant opportunity costs by investing time and resources in the democratic constitution movement. Therefore, it would be irrational for me to join the movement.

One solution to collective action problems of this sort is an agreement-making the cooperation of each contingent upon the cooperation of a group sufficient to bring about (or make more likely) the desired consequence. Perhaps, Levinson could establish a website that would enable me to pledge to take various actions in support of the movement which would be triggered by numerical thresholds. I would pledge to go discuss Levinson's ideas with at least two friends if 100 other citizens would do so as well. I would pledge to purchase and distribute ten copies of Levinson's book, when at least 1,000 other citizens had made that pledge. I would pledge to use meetup.com to organize a local meeting on the democratic constitution movement, when at least 10,000 other citizens had made a similar pledge. I would pledge to attend a mass rally when at least 100,000 other citizens had made a similar pledge. ${ }^{66}$

There are familiar problems with agreements of this sort; for example, monitoring compliance with the agreement would be costly, creating a secondary collective action problem. Compliance is crucial, because the decision whether to comply with the agreement presents the same kind of collective action problem as does cooperation in the absence of an agreement. One can imagine, however, the deployment of inexpensive mechanisms for monitoring compliance; self-reporting of compliance is likely to be reasonably accurate, and there might be reasons to believe that modest defection from the agreement would be consistent with the rationality of general compliance. My commitment of each additional increment of resources would be conditional on the success of the prior stage, so the opportunity costs would become more substantial only after the likelihood of overcoming the collective action problem became more significant: success in the early stages would provide evidence that success at later stages was feasible. At some point, the number of participants would reach a level where the commitment of resources by each individual member of the movement would decline. Once there were a few million members, then a few email

66. These examples are purely illustrative. I do not mean to suggest that agreements like this would actually be endorsed by the requisite numbers or that these agreements would result in action, even if they were executed. 
messages to one's representatives in Congress and the state legislature (plus a modest donation to the Democratic Constitution Alliance) would be sufficient.

Is this story plausible? Recent experience with political organization via the Internet suggests that it is not wholly implausible. The limited success of Howard Dean's presidential campaign and the continued ability of moveon.org to raise significant funds provide evidence that the low cost of transacting over the Internet can change the dynamic of grass roots political organizing. ${ }^{67}$ In the first phase of this campaign, the only member of the movement would be Levinson himself, and the opportunity costs for his continued involvement after publication of his book could be substantial indeed. In the next phase, concerted effort by a small group would be required in order to establish the infrastructure for a mass movement. No one is likely to claim that such a movement will necessarily succeed. A more likely assessment is that a movement for wholesale constitutional reform has only a slim possibility of success. But if a mass movement for constitutional reform does have a practical possibility of success, then the same technique might work to enable constitutional amendments on other topics through the normal Article $V$ process-undercutting Levinson's claim that such amendments are a functional impossibility.

My discussion of the speculative possibilities is even more tentative than Levinson's, and my point is not to advocate for, or against, such a movement or to claim that such a movement is inside, or outside, the feasible choice set. Rather, my very limited ambition is to attempt to deploy some of the available tools to frame the discussion in a way that points towards a rigorous, coherent, and consistent discussion of constitutional possibility.

\section{B. Scalia on the Case for Originalism}

Disclaimers first. This section of the essay investigates constitutional possibility in the context of United States Supreme Court Justice Antonin Scalia's argument for originalism as made in his famous essay Orginalism: The Lesser Evil. ${ }^{68}$ It makes no claim about originalism in general or Scalia's jurisprudence as developed in subsequent writings. ${ }^{69}$ This is a case study of the way that constitutional possibility is deployed in academic legal discourse, and not an argument against (or for) originalism (or nonoriginalism) on the merits. In addition, the discussion that follows will consider several different interpretations of Scalia's claims about possibility in his essay. Some of these interpretations are implausible as reconstructions of Scalia's own views, but that is not the purpose for which they are offered. Rather, the point of the discussion that follows is to comprehensively explore the claims that Scalia might have made about constitutional possibilities. Our aim is to understand the modality in constitutional discourse and not to assess the ultimate merits of Scalia's argument.

67. See, e.g., Adam Nagourney, Fund-Raising Puts Dean in Top Tier of Contenders, N.Y. TIMES, June 30, 2003, at 16.

68. Antonin Scalia, Originalism: The Lesser Evil, 57 U. CIN. L. REv. 849 (1989).

69. ANTONIN SCALIA, A MATTER OF INTERPRETATION (1998); see also BARNETT, supra note 2; Randy E. Barnett, An Originalism for Nonoriginalists, 45 LoY. L. REv. 611 (1999); Lawrence B. Solum, The Supreme Court in Bondage: Constitutional Stare Decisis, Legal Formalism, and the Future of Unenumerated Rights, 9 U. PA. J. Const. L. 155 (2006). 
Finally, this discussion of Scalia's argument will not differentiate between different forms of originalism. ${ }^{70}$

With those caveats out of the way, let's take a look at the way that possibility figures into Scalia's argument for originalism:

$[T]$ he central practical defect of nonoriginalism is fundamental and irreparable: the impossibility of achieving any consensus on what; precisely, is to replace original meaning, once that is abandoned. ${ }^{71}$

Thus, an impossibility claim is at the very heart of Scalia's case for originalism as "the lesser evil": the impossibility of achieving consensus on an alternative to original meaning is the "central practical defect of nonoriginalism."

But what claim did Scalia make? Scalia's statement is brief and enigmatic. The phrase, "the impossibility of achieving consensus," fails to specify a sense of impossibility, the agent or agents for whom achieving consensus is impossible, and so forth. In order to assess Scalia's claim, we need to unpack it, sorting out the various meanings that Scalia might have intended.

On one interpretation, which we can call the "conceptual interpretation," Scalia's argument seems to suffer an obvious defect. Scalia divides the set of constitutional theories into two subsets: originalist and nonoriginalist. He then argues that the defect of the set of nonoriginalist theories is that it is impossible for them to form a consensus on what is to replace originalism; this defect is obviously not present in originalism, which by definition is able to form a consensus on originalism itself. If we interpret Scalia as making a conceptual claim, then his argument is sound (valid with true premises), but trivial. The members of the subset of originalist theories are, by definition, originalist. The members of the subset of nonoriginalist theories are, as a matter of fact and definition, different from one another-their only common characteristic is that they are nonoriginalist. Brennan's "living constitutionalism" is different from Dworkin's "law as integrity."72 Given the way that Scalia has drawn the lines and the fact that nonoriginalist theories differ from one another, "consensus" among them is logically impossible. ${ }^{73}$ This argument is trivial, because it can be made on behalf of any constitutional theory. For example, if we divide constitutional theories into Dworkinian and non-Dworkinian theories, it is impossible for the non-Dworkinian theories to form a consensus. So this cannot be the kind of impossibility claim that Scalia is making - at least if we are to interpret him charitably.

How else might we interpret Scalia's impossibility claim? Scalia might be claiming that it is impossible for some set of judges (the current bench or perhaps the politically

70. Among the forms of originalism that have played a prominent role in recent discussions are "original intentions" and "original meaning." See Lawrence B. Solum, Legal Theory Lexicon 019: Originalism, http://lsolum.typepad.com/legal_theory_lexicon/2004/01/legal_ theory le 1.html (Jan. 18, 2004).

71. Scalia, supra note 68 , at $862-63$.

72. See generally DWORKIN, supra note 55; William J. Brennan, Jr., The Constitution of the United States: Contemporary Ratification, 27 S. TEX. L. REV. 433, 438 (1986).

73. That is, it is logically impossible for different constitutional theories to be identical to one another. Scalia cannot charitably be interpreted as making the much stronger claim that there is no possible world in which there is one and only one nonoriginalist theory (or family of sufficiently similar theories). 
feasible bench) to form a consensus on any nonoriginalist theory. Understanding this interpretation of Scalia's argument requires us to specify the relevant agent: for whom would consensus on a particular nonoriginalist theory be impossible. If his claim is about the current bench (e.g., all federal judges or all Supreme Court Justices), then Scalia's argument faces severe difficulties. Scalia's claim would be trivially false if viewed as a claim about what is possible for the federal bench as a collective actor: it is not impossible for the collectivity of federal judges to adopt Dworkin's theory of law as integrity. But if Scalia's claim is not a claim about the collectivity, then it runs into a double standard problem. Suppose we hold the attitudes of judges about the proper methodology for constitutional interpretation constant. It will then be the case that consensus on any one nonoriginalist theory is impossible, but if we apply this same standard to originalism, it becomes apparent that consensus on originalism would also be impossible. Just as the current set of judges or Justices do not agree on any one nonoriginalist theory, they also do not agree on originalism. For these reasons, the "current bench interpretation" of Scalia's impossibility claim is implausible. Either judges can change their minds or they can't. If they can, then they could agree on some rival of originalism; if they cannot, then consensus on originalism is no more possible than is consensus on one of originalism's rivals.

Yet another variation of Scalia's impossibility claim might focus on the possible configurations of the future bench-given appointments process and political realities. Call this the "politically feasible bench interpretation." That is, Scalia might be arguing that it is politically feasible to appoint an originalist federal bench, but that it would not be politically feasible to appoint federal judges who would agree on a single nonoriginalist approach. If this were Scalia's claim, then it seems unlikely to be correct as an empirical matter-at least over the long run. There is no consensus among existing political actors that originalist judges are acceptable. Of course, there may be agreement on the abstract proposition that judges should enforce the commands of the constitutional text, and even that historical evidence of original meaning should be considered. But that agreement is likely to become shaky as soon as particular constitutional controversies-such as the death penalty, abortion, or affirmative action - enter into the discussion. It may be possible that political alignment plus a cluster of Supreme Court vacancies would permit appointments creating a majority of five originalists on the Supreme Court, but if that is the standard then it would seem that equally plausible scenarios would enable the appointment of a majority of five nonoriginalist justices who agreed on a single rival to originalism.

Suppose we reject the conceptual current-bench politically-feasible-bench interpretations of Scalia's argument. How else might we interpret his impossibility claim? Another alternative is suggested by the following passage:

Now the main danger in judicial interpretation of the Constitution-or, for that matter, in judicial interpretation of any law-is that the judges will mistake their own predilections for the law. Avoiding this error is the hardest part of being a conscientious judge; perhaps no conscientious judge ever succeeds entirely. Nonoriginalism, which under one or another formulation invokes "fundamental values" as the touchstone of constitutionality, plays precisely to this weakness. It is very difficult for a person to discern a difference between those political values that he personally thinks most important, and those political values that are "fundamental to our society." Thus, by the adoption of such a criterion judicial personalization of the law is enormously facilitated. (One might reduce this danger by insisting that the new "fundamental values" invoked to replace original 
meaning be clearly and objectively manifested in the laws of the society. But among all the varying tests suggested by nonoriginalist theoreticians, I am unaware that that one ever appears. Most if not all nonoriginalists, for example, would strike down the death penalty, though it continues to be widely adopted in both state and federal legislation. $)^{74}$

What light does this passage shed on Scalia's impossibility claim? First, it clarifies that by "nonoriginalism," Scalia actually means to refer to theories of interpretation that focus on those values that are fundamental to our society. Second, what Scalia claims is impossible seems to be discernment of the difference between those values that are fundamental to our society and those values that the individual (e.g., the judge or other official interpreting the Constitution) believes are fundamental. These two points suggest a reconstruction of Scalia's claim. Given the fundamental values approach, it is difficult for individuals to discern the difference between their own values and the values that are fundamental to our society. Some individuals will succeed, but others will fail. Given that some will fail and given the fact of pluralism (that there are a plurality of views about which values are fundamental), no consensus on the content of the values that are fundamental to our society can emerge. Therefore, it is impossible for adherents to a fundamental values approach to reach agreement on what the Constitution means.

How does Scalia's argument fare if judged by the standards for modal constitutional argument set out above $?^{75}$ The first standard requires that the criteria for modal claims be articulated: it seems reasonably clear that Scalia does not attempt (either explicitly or implicitly) to articulate the criteria for impossibility that forms the basis of his claim. The second standard requires explicit statement of the evidence for impossibility. Scalia offers no evidence for his claim, although he may have offered an explanation of the mechanism - that discernment is difficult. The third standard calls for avoidance of double standards. Application of the third standard is difficult, because of the ambiguity and vagueness of Scalia's impossibility claim. Is consensus on original meaning possible (or "less difficult") than consensus on "the values that are fundamental to our society?" A good answer to that question will take us too far afield of the focus of this inquiry - the logic of modality in constitutional discourse.

\section{Conclusion: The Problem of False Constitutional Necessity}

This Essay began with the problem of illusory constitutional possibilities. That problem can be addressed with a variety of tools. Constitutional theorists can recognize that there is an important role for ideal constitutional theory, while recognizing the dangers of bad utopianism. They can play close attention to idea of a constitutional second best and rigorously define the criteria for inclusion in the feasible choice set. Constitutional theorists can explicitly articulate assumptions about agency and the scope of decision. They can disambiguate the various sense of possibility and utilize the tools of positive constitutional theory to construct sound arguments about constitutional possibility.

74. Scalia, supra note 68 , at 863 .

75. See discussion supra Part III.B. 
The problem of illusory constitutional possibility has an evil twin: the problem of false constitutional necessity. ${ }^{76}$ It requires little effort to make the case that any truly significant constitutional change is a practical impossibility and draw the conclusion that questions of constitutional design should be off the table of constitutional theory. At any given time, the chance that action by any given individual would make a crucial contribution and enable a constitutional reform that would otherwise fail surely approachs zero. Taken to an extreme, this approach would limit the domain of constitutional theory to the constitutional questions that are contestable given the current configuration of judicial electoral politics. That is, we might limit our horizon of constitutional possibilities to adjacent possible worlds that are practically accessible to key political and constitutional actors in actual world.

Limiting our constitutional horizons in this way would be a mistake. The Constitution of 1789, the Reconstruction Amendments, popular election of Senators, and the franchise for women are all part of the history of the actual world. Although some constitutional possibilities may be illusory, it is surely true that in the long run, there are few constitutional necessities that take serious options off the table. And if one believes that normative constitutional theory should take the long view-should seek constitutional knowledge with relevance that transcends particular moments in constitutional history, then most claims of constitutional necessity are false. Practical constitutional theory operates in the space between illusory constitutional possibilities and true constitutional necessity.

76. Roberto MangabeiRa UNGer, False NeCESSITY: ANTINECESSTTARIAN SOCIAL Theory IN THE SERVICE OF RADICAL DEMOCRACY (rev. ed., 2004). 
